\title{
Mendalami Informasi dengan Bertabayyun Menurut Al-Qur'an di Tinjau Dari Tafsir Klasik dan Kontemporer
}

\author{
Sulhi M. Daud Abdul Kadir ${ }^{1 *}$, Sahrizal Vahlepi ${ }^{2}$ \\ ${ }^{1}$ Program Studi Ilmu Hukum, Fakultas Hukum, Universitas Jambi \\ ${ }^{2}$ Program Studi Pendidikan Bahasa Arab, Fakultas Keguruan dan Ilmu Pendidikan, Universitas Jambi \\ *Correspondence email: sulhidaud@gmail.com, sahrizalvahlepi@unja.ac.id
}

\begin{abstract}
Abstrak. Penelitian ini bertujuan untuk melihat pentingnya bertabayyun atau mendalami suatu informasi yang diterima menurut Al-Qur'an. Karena saat ini media sosial merupakan media komunikasi yang efektif, tranparasi dan efisien. Pendekatan yang digunakan dalam penelitian ini adalah pendekatan kualitatif, dengan jenis penelitian library research. Sumber data primer dalam penelitian ini adalah kitab tafsir (Ibnu Jarir Ath-Thobari, Ibnu Katsir, Al-Misbah, dan Al-Azhar) dan data skunder skripsi, jurnal, dan artikel yang membahas tentang tabayyun, serta kamus, dan buku-buku yang yang relevan. Hasil penelitian ini menyimpulkan bahwa menurut berbagai pendapat mufassir dari kalangan klasik dan kontemporer ialah 1) Adanya larangan untuk tergesa-gesa dalam mengambil tindakan terhadap suatu berita 2) fasiq adalah sebagai seorang pendusta dan berbuat kekeliruan atau rusak. 3) Setiap berita harus disaring jangan sampai melangkah atau bertindak dalam keadaan yang tidak wajar 4) Informasi yang datang jangan langsung dibenarkan atau ditidakkan, tetapi harus didalami dulu kebenarannya.
\end{abstract}

Kata Kunci: Bertabayyun; Tafsir Klasik Dan Kontemporer

Abstract. This study aims to see the importance of tabayyun or deepening an information received according to the Qur'an. Because today social media is an effective, transparent and efficient communication medium. the approach used in this research is a qualitative approach, with the type of research library research. The primary data sources in this study are the books of commentary (Ibn Jarir Ath-Thobari, Ibn Kathir, Al-Misbah, and Al-Azhar) and secondary data on theses, journals, and articles that discuss tabayyun, as well as dictionaries, and books related to tabayyun. which is relevant. The results of this study conclude that according to various opinions of mufassir from classical and contemporary circles, namely 1) There is a prohibition on hasty in taking action on a news 2) Fasiq is a liar and makes mistakes or is damaged. 3) Every news must be filtered so that they do not step or act in an unnatural situation. 4) The information that comes is not justified or rejected, but the truth must be investigated first

Keywords: Bertabayyun; Classical and Contemporary Interpretation

\section{PENDAHULUAN}

Mencari kejelasan atau kebenaran suatu fakta yang terjadi merupakan pengertian dari tabayyun. Dalam kehidupan bersosial tentunya akan banyak menemukan bahkan mengalami beraneka kejadian dan itu tidak terlepas dengan yang namanya pemberitaan atau informasi. Di zaman millennial ini segala berita atau informasi dengan mudah di dapatkan, kecanggihan alat informasilah yang menjadi tersebar luasnya berita atau informasi keseluruh belahan dunia.

Kecanggihan teknologi informasi yang berkembang pesat, mengantarkan dunia masyarakat lokal menjadi global. Dan perkembangan teknologi informasi tersebut telah melahirkan ruang gerak yang baru, tentunya tanpa disadari bahwa manusia telah hidup dalam dua kehidupan, yaitu kehidupan yang nyata dan maya. Oleh karena itu media sosial yang dilahirkan dari kecanggihan teknologi informasi, memiliki andil yang sangat besar dalam mempermudah manusia berkomunikasi, bersosialisai, dan berinteraksi.

Masyarakat haruslah cerdas dalam memilah berita, mengecek dan menguji keakuratan berita sama halnya dengan penyampaian berita. Namun, baik peyampai berita ataupun penerimanya, keduanya harus memahami etika yang berlaku. Ketika seseorang menerima berita dari berbagai media, mereka cenderung cepat menyebar luaskan kembali tanpa memeriksa terlebih dahulu kebenaran dalam suatu berita tersebut, hal ini bertolak belakang dengan sikap yang harus dilakukan oleh umat muslim seperti yang tertulis dalam surah al-Hujarat ayat 6, berikut ini:

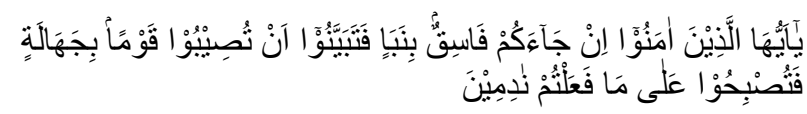

"Hai orang-orang yang beriman, jika datang kepadamu orang fasik membawa suatu berita, maka periksalah dengan teliti agar kamu tidak menimpakan suatu musibah kepada suatu kaum tanpa mengetahui keadaannya yang menyebabkan kamu menyesal atas perbuatanmu itu."

Pada ayat-ayat sebelumnya Allah menjelaskan tuntutan bagaimana bertatakrama dengan Rasulullah SAW, lalu kemudian pada ayat ini Allah menjelaskan bagaimana berlaku dengan sesama manusia, termasuk kepada orang fasik. Pada ayat ini Allah memberikan tuntunan kepada kaum muslimin agar berhati-hati dalam 
menerima berita terutama jika bersumber dari orang yang fasik. Perlunya berhati-hati dalam menerima berita adalah untuk menghindarkan penyesalan akibat tindakan yang diakibatkan oleh berita yang belum diteliti kebenarannya terlebih dahulu.

Ayat ini memberikan pedoman kepada orangorang mukmin supaya berhati-hati dalam menerima sebuah berita atau informasi, terutama jika bersumber dari seorang yang fasik. Maksud ayat ini adalah perlunya diadakan penelitian dahulu mengenai kebenaran suatu berita. Mempercayai suatu berita tanpa diselidiki dahulu kebenarannya, besar kemungkinan akan membawa korban jiwa dan harta sia-sia, dan hanya menimbulkan penyesalan belaka. Sebagai masyarakat yang cerdas harus lebih kritis dan melakukan tabayyun terhadap informasi yang diperoleh. Layaknya pepatah Arab mengatakan "al-Khabar ka al-ghubar" yang artinya ialah informasi itu bagaikan debu yang belum jelas kebenarannya.

Oleh karena itu, berdasarkan penjelasan di atas maka tulisan ini akan memaparkan tentang mendalami informasi dengan bertabayyun analisis studi tafsir klasik dan kontemporer surat alhujurat ayat 6 tafsir ibnu jarir ath-Thobari, Ibnu katsir, Al-Mishbah dan Al-Azhar.

\section{Tinjauan Pustaka}

Pada bagian tinjauan pustaka ini memaparkan beberapa literatur yang relevan untuk dijelaskan. Ada beberapa karya tulis terdahulu dengan topik tabayyun yang penulis jadikan perbandingan disini.

karya Dina Nasicha, skripsi pada fakultas ushuluddin dan humaniora UIN Walisongo, 2016, berjudul "Makna Tabayyun dalam Alquran (Studi Perbandingan Antara Tafsir Al-Muyassar dan Tafsir AlMisbah)" Skripsi ini membahas secara khusus komparasi pemikiran M.Quraish Shihab dan Aidh al-Qarni dalam tafsir tentang ayat tabayyun, baik dari segi metode maupun pandangannya.

Karya Amirulloh, berjudul "Jurnalistik dan konsep Tabayyun dalam Alquran: Analisis tayangan infotaiment kiss di Indosiar" skripsi pada fakultas dakwah dan komunikasi UIN Syarif Hidayatullah, dalam skripsi ini penulis mengemukakan bahwa Tabayyun merupakan salah satu sikap yang sangat penting untuk selalu dipraktikan dalam kehidupan bermasyarakat. Banyak pertikaian dan perselisihan baik dalam skala terkecil, seperti antar dua orang individu hingga skala terbesar seperti peperangan global, disebabkan oleh tuduhantuduhan tidak benar atau pemahaman keliru dalam membaca sikap orang lain.

Karya Muhammad atohillah, berjudul "Nilai-Nilai Kemasyarakatan dalam Surat al-Hujurat (Studi atas penafsiran Ahmad Mustafa al-Maragi dalam tafsir alMaragi)" skripsi pada Fakultas Ushuluddin Studi agama dan pemikiran Islam, Jurusan Tafsir Hadis, UIN Sunan Kalijaga. Dalam skripsi ini dikemukakan bahwa setiap orang bermasyarakat pasti ada konflik bertetangga atau berinteraksi sosial. Dan untuk memecahkan atau mencari solusi dalam konflik sosial maka penulis mengembalikan ke Alquran.

Karya Arifin (2018) berjudul "Kajian Komunikasi Massa pada Surah Al-Hujurat Ayat 6" berupaya mengintegrasikan teori komunikasi massa dengan nilainilai pada surah Alhujurat ayat 6 , di bawah semangat kontekstualisasi ajaran Islam terhadap perkembangan zaman. Artikel ini menyimpulkan konsep tabayyun berisi kehati-hatian dan ketelitian dalam menyikapi informasi maupun media penyampai infomasinya.

Muhammad Usman Noor (2018) menulis "Penilaian Kualitas Informasi sebagai Bentuk Sikap Tabayyun ketika Menerima Informasi di Sosial Media dan Internet." Noor menautkan urgensi tabayyun dengan metode penilaian informasi yang berkualitas melalui tiga aspek utama, yaitu reputasi penanggung jawab isi informasi, relevansi isi informasi, dan representasi informasi.

Beberapa literatur diatas sangat jelas bahwa betapa pentingnya bertabayyun karena disetiap kehidupan bermasyarakat tentunya pasti menemukan konflik dalam berinteraksi sosial. Dengan demikian artikel penulis ini mendukung sekali pernyataan tersebut diatas, dan lebih lanjut penulis akan menguraikan pentingnya bertabayyun dalam prespektif tafsir klasik dan kontemporer.

\section{METODE}

Penulis mengumpulkan data berupa istilah-istilah dan penjelasannya dari beberapa sumber yang ada di dalam literatur, sebagai data primer yaitu kitab tafsir Ibnu Jarir Ath-Thobari dan Ibnu Katsir yang mewakili tafsir klasik, Al-Misbah dan Al-Azhar yang mewakili tafsir kontemporer. Data skunder berupa skripsi, jurnal, dan artikel yang membahas tentang tabayyun, serta kamus, dan buku-buku yang membahas informasi dan komunikasi dan topik-topik yang relevan. (Arikunto, 1998) Menurut Mestika Zed karya tulis semacam ini merupakan riset pustaka atau penelitian kepustakaan yaitu peneliti berhadapan dengan teks atau nash. (Zed, 2004) Kemudian penulis melakukan analisis tematik dengan melihat hubungan antar konsep, dan menarik kesimpulan secara induktif. Pembahasan dimulai dengan menafsirkan ayat tabayyun, menjelaskan asbabunnuzul ayat, diikuti uraian mengenai urgensi tabayyun dalam perespektif tafsir klasik dan kontemporer dan terakhir adalah kesimpulan.

\section{HASIL DAN PEMBAHASAN \\ Bertabayyun analisis tafsir ibnu Jarir Ath-Thobari QS Al-Hujurat ayat 6}

Maksudnya adalah, hai orang-orang yang membenarkan Allah dan Rasul-Nya, jika datang kepada kalian orang fasik membawa suatu berita maka periksalah dengan teliti. Ahli qira'at berbeda pendapat dalam membaca firman Allah Ta'ala, -fatabayyanu." 
Ahli qira'at Madinah umumnya membacanya fatatsabbatu, dengan huruf tsa'. Disebutkan bahwa ini termaktub dalam mushaf Abdullah. Sebagian ahli qira'at lainnya membacanya fatabayyanu, dengan huruf ya'. Maknanya yaitu, tunggulah hingga kalian mengetahui kebenarannya. Jangan terburu-buru menerimanya. Begitu juga makna lafazh fatabayyanu. (Jaefar, 2007)

Pendapat yang benar tentang hal ini adalah, kedua-duanya merupakan qira'at yang sudah dikenal, dan maknanya pun tidak jauh berbeda. Oleh karena itu, dengan qira'at mana saja yang digunakan, telah dianggap benar. Disebutkan bahwa ayat ini turun pada Walid bin Uqbah bin Abi Mu'ith. Riwayat yang mendasari pemyataan ini adalah:

Abu Kuraib menceritakan kepada kami, ia berkata: Ja'far bin Aun menceritakan kepada karni dari Musa bin Ubaidah, dari Tsabit (maula Ummu Salamah), dari Ummu Salamah, dia berkata, "Rasulullah SAW mengutus seorang laki-laki untuk mengambil sedekah bani Mushthaliq setelah peperangan. Mendengar hal ini, warga bani Mushthaliq berniat menyambut laki-laki tersebut, sebagai bentuk penghormatan terhadap perintatr Rasulullah SAW.

Namun syaitan membisikkan ke dalam pikiran laki-laki tersebut bahwa mereka hendak membunuhnya, maka laki-laki tersebut kembali kepada " Rasulullah SAW dan berkata, 'sesungguhnya bani Mushthaliq tidak mau menyerahkan sedekah mereka Rasulullah SAW pun marah, begitu juga kaum muslim.

Sementara itu, warga bani Mushthaliq yang mengetahui kembalinya laki-laki tersebut, segera mendatangi Rasulullah SAW. Mereka tiba ketika Rasulullah SAW sedang melakukan shalat Zhuhur, maka mereka ikut shalat bersama beliau. Selesai shalat, mereka berkata, 'Kami berlindung kepada Allah dari kemurkaan Allah dan kemarahan Rasul-Nya. Engkau telah mengutus seseorang yang benar kepada kami, maka kami senang dengan hal itu dan sangat gembira, namun di tengah perjalanan dia kembali kepada engkau. Kami khrawatir hal ini merupakan pertanda murka Allah dan Rasul-Nya'. Mereka terus berbicara dengan Rasulullah SAW hingga Bilal datang dan mengumandangkan adzan Ashar. Lalu turunlah firrman Allah, "Hai orang-orang yang beriman jika datang kepadamu orang fasik membawa suatu berita, maka periksalah dengan teliti, agar kamu tidak menimpakan suatu musibah kepada suatu kaum tanpa mengetahui keadaannya yang menyebabkan kamu menyesal atas perbuatanmu itu. (Ja"far, 2007)

Muhammad bin Sa'd menceritakan kepadaku, ia berkata: Ayahku menceritakan kepadaku ia berkata: Pamanku menceritakan kepadaku ia berkata: Ayahku menceritakan kepadaku dari ayahrya dari Ibnu Abbas, tentang firman Allah, "Hai orang-orang yang beriman jika datang kepadamu orang fasik membawa suatu berita, maka periksalah dengan teliti, agar kamu tidak menimpakan suatu musibah kepada suatu kaum tanpa mengetahui keadaannya yang menyebabkan kamu menyesal atas perbuatan itu dia berkata Rasulullah SAW menguhrs Walid bin Uqbah bin Abi Mu'itb, seseorang dari Bani Amr bin Umallyd dan seseorang dari kalangan Bani Abi Mu'ith ke Bani Mushthaliq untuk mengambil sedekah dari mereka Ketika mendengar rencana kedatangan mereka bani Murshthaliq sangat gembira dan keluar unttuk menyambut utusan Rasulullah SAW tersebut.

Sementara itu, ketika diceritakan kepada Walid bahwa bani Mushtbaliq keluar untuk menyambutnya, dia justru kembali kepada Rasulullah SAW dan berkata" 'Wahai Rasutullah sesugguhnya bani Mushthaliq tidak mau mengeluarkan sedekah (zakat)'. Rasulullah SAW pun sangat marah. Saat beliau berkata dalam hati bahwa beliau akan memerangi mereka, datanglah delegasi (dari bani Mushthaliq), mereka berkata wahai Rasulullah sesungguhnya diceritakan kepada karni bahwa utusan engkau kembali pulang di tengah perjalanan. Kami khawatir kembalinya itu karena surat dari engkau yang datang kepadanya sebab sesuatu yang mernbuat engkau marah tertradap karni. Sesungguhnya kami berlindung kepada Allah dari kemurkaan-Nya dan kernaratran Rasul-Nya'. Saat itu Rasulullah SAW telah mengepumg dan hendak menyerang mereka. Allah Ta'ala lalu menurunkan kebenaran pemyataan mereka dalam Al qur'an, "Hai orang-orong yang beriman jika datang kepadamu orang fasik membawa suatu berita, maka periksalah dengan teliti, agar kamu tidok menimpakan suatu musiboh kepada suatu kaum tanpa mengetahui keadaannrya yang menyebabkan kamu menyesal atas perbuatanmu itu,

Takwil fiman Allah:

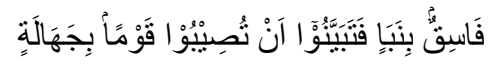

Maksudnya adalah maka periksalah dengan teliti, agar kalian tidak menimpakan suatu musibah kepada suatu kaum yang tidak bersalah karena ketidaktahuan kalian akan keadaan mereka. Dengan demikian kita dilarang untuk tergesa-gesa atau gegabah dalam mengambil tindakan terhadap suatu berita, karena bisa berakibat sangat fatal. Oleh karena itu periksa dengan teliti sehingga jelas adanya suatu berita tersebut. FirmanNya"Yang menyebabkan kamu menyesal atas perbuatanmu itu," maksudnya adalah, yang menyebabkan kalian menyesal karena kalian menimpakan musibah tersebut kepada mereka.

Sebelum penyesalan menghampiri dikemudian hari akibat tergesa-gesa atau gegabah dalam mengambil tindakan terhadap suatu berita, karena tidak diperiksa dengan teliti suatu berita tersebut, maka pada akhir ayat Allah mengingatkan bahwa ada sebuah penyesalan yang menanti akibat dari sebuah tindakan. 


\section{Bertabayyun analisis tafsir Ibnu Katsir QS Al- Hujurat ayat 6}

Sebagai bentuk kewaspadaan, pada ayat ini Allah memerintahkan kepada orang-orang yang beriman supaya benar-benar meneliti berita yang berasal dari orang-orang yang fasik, sehingga nantinya tidak ada yang mengambil keputusan dan melakukan tindakan berdasarkan perkataan dari orang fasik tersebut. Predikat orang fasik pada saat itu adalah sebagai seorang pendusta dan berbuat kekeliruan, ketika seseorang memberikan keputusan dan bertindak berdasarkan ucapan dari orang fasik itu berarti dia telah mengikuti jejaknya. Sementara Allah melarang untuk mengikuti jalan orang-orang yang berbuat kerusakan.

Terdapat perbedaan pada beberapa kelompok ulama bahwa melarang untuk menerima berita yang diperoleh dari orang yang tidak diketahui keadaannya di karenakan adanya kemungkinan orang tersebut fasik. Namun ada pula kelompok lain yang menerimannya, karena menurut mereka bahwa kami ini hanya diperintahkan untuk memberikan kepastian berita yang dibawa oleh orang fasik, sedangkan orang ini tidak terbukti sebagai seorang fasik karena tidak diketahui keadaannya.

Mayoritas ulama tafsir menyebutkan bahwa ayat ini diturunkan berkenaan dengan al-Walid bin Uqbah bin Abi Mu'ith saat ketika ia diutus Rasulullah SAW untuk mengambil zakat Bani Musthaliq. Dan telah diriwayatkan dari berbagai jalur, riwayat yang terbaik adalah yang telah diriwayatkan oleh Imam Ahmad di dalam kitab Musnadnya melalui riwayat pemimpin Bani Musthaliq, yaitu Al-Harits ibnu Abu Dirar, orang tua siti Juwairiyah Ummul Mu'minin r.a.

Imam Ahmad meriwayatkan, Muhammad bin Sabiq memberitahu kami, 'Isa bin Dirar memberitahu kami, bapakku memberitahuku, bahwasannya ia pernah mendengar al-Harith bin Abi Dirar al-Khuza'i bercerita: "aku pernah datang menemui Rasulullah SAW, maka belia mengajakku masuk Islam. Maka aku pun memeluk Islam dan mengikrarkannya. Kemudian beliau mengajak Rasulullah, aku akan pulang kepada rakyatku dan aku akan ajak mereka untuk masuk Islam dan mengumpulkan zakatnya, dan kirimkanlah seorang utusan kepadaku ya Rasulullah, sekitar waktu begini dan begini guna membawa zakat yang telah aku kumpulkan kepadamu. (Abdullah, 2009)

Setelah al-Harith mengumpulkan zakat dari orangorang yang mematuhi seruannya dan telah sampai pada masa kedatangan utusan Rasulullah SAW, ternyata utusan Rasulullah tersebut tertahan di tengah jalan dan tidak datang menemuinya. Al-Harith pun mengira bahwasanya telah turun kemurkaan dari Allah dan Rasul-Nya pada dirinya. Ia pun segera memanggil para pembesar kaumnya dan mengatakan kepada mereka: "Sesungguhnya Rasulullah SAW telah menetapkan waktu kepadaku, di mana beliau akan mengirimkan utusannya kepadaku untuk mengambil zakat yang aku kumpulkan, dan bukan kebiasaan Rsulullah SAW untuk menyalahi janji, dan aku tidak melihat tertahannya utusan beliau melainkan karena kemakmuran Allah. Oleh karena itu, marilah bersama-sama menemui Rasulullah SAW untuk menyampaikan harta zakat kita sendiri.

Bertepatan dengan itu Rasulullah mengutus alWalid bin 'Uqbah untuk menemui al-Harith guna mengambil zakat yang telah dikumpulkannya. Ketika alWalid berangkat dan sudah menempuh beberapa jarak , tiba-tiba ia merasa takut dan kembali pulang, lalu menemui Rasulullah SAW seraya berkata: "Ya Rasulullah sesungguhnya al-Harith menolak memberikan zakat padaku, bahkan ia bermaksud membunuhku. "Maka Rasulullah pun marah dan mengirim utusan kepada al-Harith. Dan al-Harith serta para sahabatnya pun bersiap-siap berangkat. Ketika utusan beliau meninggalkan kota Madinah, alHarith bertemu dengan mereka. Maka mereka berkata: "Inilah al-Harith". Dan pada saat al-Harith menghampiri mereka, ia berkata: "kepada siapa kalian diutus?" "Kepadamu", jawab mereka. "Lalu untuk apa kalian diutus kepadaku?" tanya al-Harith lebih lanjut. Mereka menjawab: "sesungguhnya Rasulullah SAW telah mengutus al-Walid bin 'Uqbah kepadamu, dan ia mengaku bahwa engkau menolak memberikan zakat dan bahkan engkau akan membunuhnya". Maka al-Harith berkata: "tidak benar". Demi Rabb yang telah mengutus Muhammad SAW dengan kebenaran, aku sama sekali tidak pernah melihatnya dan tidak juga ia mendatangiku.

Dan setelah al-Harith menghadap Rasulullah SAW, maka bertanya: "apakah engkau menolak menyerahkan zakat dan bermaksud membunuh utusanku?" ia menjawab: "tidak, demi Rabb yang telah mengutusmu dengan kebenaran, aku sama sekali tidak melihatnya dan tidak pula ia mendatangiku, (tidak kunjung datang) dan aku takut akan muncul kemarahan dari Allah Ta'ala dan Rasul-nya". Pada saat itu turunlah surah al-Hujurat: 6-8.

Ibnu Abi Hatim meriwayatkan hadits ini dari AlMunzir Ibnu Syazan At-Tammar, dari Muhammad IBnu Sabiq dengan sanad yang sama. Imam Tabrani telah meriwayatkannya pula melalui hadits Muhammad Ibnu Sabiq dengan sanad yang sama, hanya didalam riwayatnya disebutkan Al-Haris Ibnu Siran, tetapi sebenarnya adalah Al-Haris Ibnu Dirar, seperti yang disebutkan dalam riwayat di atas. (Abdullah, 2009)

Dari beberapa riwayat tersebut diatas, mengenai cerita utusan Rasul yaitu al-Walid bin 'Uqbah untuk menemui al-Harith guna mengambil zakat yang telah dikumpulkannya, namun ketika al-Walid sudah berangkat dan sudah menempuh beberapa jarak, tiba-tiba ia merasa takut dan kembali pulang, lalu menemui Rasulullah SAW. Dan membawa suatu berita bahwa alHarith menolak memberikan zakat padaku, bahkan ia bermaksud membunuhku. Kemudian "Maka Rasulullah pun marah dan mengirim utusan kepada al-Harith. Dan 
pada kenyataannya al-Harith tidak melihat dan tidak didatangi oleh al-Walid bin 'Uqbah, kemudian setelah itu al-Harith pun menghadap Rasulullah dan terjadilah proses tabayyun.

Cerita tersebut memberikan pesan terhadap kita bahwa betapa pentingnya melakukan tabayyun sebagaimana yang telah Rasulullah lakukan, dengan demikian dapat menuntaskan berita yang belum jelas kontennya dan tidak merugikan bagi siapapun yang terlibat didalamnya. Dengan demikian jika ada suatu berita yang disampaikan terlebih lagi yang menyampaikan orang fasiq, jangan serta merta menerima begitu saja tetapi hendaklah terlebih dahulu ditelusuri tentang kebenaran suatu berita tersebut guna menghindari kerugian dan penyesalan dikemudian hari akibat mengambil keputusan dengan terburu-buru.

\section{Bertabayyun analisis tafsir Al-Misbah QS Al- Hujurat ayat 6}

Menurut mayoritas ulama, turun menyangkut kasus al-Walid ibn Uqbah Ibn Abi Mu'ith yang ditugaskan Nabi SAW menuju ke Bani al Musthalaq untuk memungut zakat. Ketika anggota masyarakat yang dituju itu mendengar tentang kedatangan utusan Nabi SAW yakni al-Walid, mereka keluar dari perkampungan mereka untuk menyambutnya sambil membawa sedekah mereka, tetapi al-Walid menduga bahwa mereka akan menyerangnya. Karena itu ia kembali sambil melaporkan kepada Rasul SAW bahwa Bani al-Musthalaq enggan membayar zakat dan bermaksud menyerang Nabi SAW. Rasul SAW marah dan mengutus Khalid ibn Walid menyelidiki keadaan sebenarnya sambil berpesan agar tidak menyerang mereka sebelum duduk persoalan menjadi jelas. Khalid mengutus seorang informannya menyelidiki perkampungan Bani al-Musthalaq yang ternyata masyarakat desa itu mengumandangkan adzan dan melaksanakan shalat berjamaah. Khalid kemudian mengunjungi mereka lalu menerima zakat yang telah mereka kumpulkan. Riwayat lain menyatakan bahwa justru mereka yang datang kepada Rasul SAW menyampaikan zakat sebelum Khalid ibn alWalid melangkah ke perkampungan mereka. (Quraish Shihab, 2009)

Sikap Rasulullah ketika menghadapi permasalahan tersebut diatas merupakan sebuah tindakan yang patut kita teladani. Dimana beliau mengutus seseorang untuk menyelidiki berita yang telah diterimanya, mencari kejelasan suatu berita tersebut sampai menjadi jelas adanya.

Adapun ayat di atas menggunakan kata (i in) yang berarti jika yang biasa digunakan untuk sesuatu yang diragukan atau jarang terjadi. Ini mengisyaratkan bahwa kedatangan seorang fasik kepada orang-orang beriman diragukan atau jarang terjadi. Hal itu disebabkan orang-orang fasik mengetahui bahwa kaum beriman tidak mudah dibohongi dan mereka akan meneliti kebenaran setiap informasi sehingga seorang fasik dapat dipermalukan dengan kebohongannya.

Dengan demikian, sebuah isyarat yang jarang terjadi bukan berarti kita dapat menghindari bilamana suatu saat akan terjadi. Tersimpan makna kehati-hatian dalam penjelasan tersebut diatas, agar kita sebagaimana orang yang beriman selalu waspada dan tidak terburuburu dalam mengambil tindakan dan pada akhirnya akan terbukti sebuah kebohongan yang telah disampaikan oleh orang fasik.

Kata fasiq terambil dari kata fasaqa yang biasa digunakan untuk melukiskan buah yang telah rusak atau terlalu matang sehingga terkelupas kulitnya. Seorang yang durhaka adalah orang yang keluar dari koridor agama akibat melakukan dosa besar atau sering kali melakukan dosa kecil.

Kata naba' digunakan dalam arti berita yang penting. Berbeda dengan kata khabar yang berarti kabar secara umum, baik penting maupun tidak. Dari sini, terlihat perlunya memilah informasi apakah itu penting atau tidak dan memilah pula pembawa informasi apakah dapat dipercaya atau tidak. Orang beriman tidak dituntut untuk menyelidiki kebenaran informasi dari siapa pun yang tidak penting, bahkan didengarkan tidak wajar, karena jika demikian akan banyak energi dan waktu yang dihamburkan untuk hal-hal yang tidak penting.

Perlu kita pahami bahwa hanya informasi atau berita penting saja dan seorang pembawa berita apakah dapat dipercaya atau tidak saja yang dipilih, maka selain itu orang beriman tidak dituntut untuk menyelidiki kebenaran informasi itu. Dikarenakan dapat membuang waktu saja untuk hal yang tidak penting.

Kata bi jahalah dapat berarti tidak mengetahui dan dapat juga diartikan serupa dengan makna kejahilan, yakni perilaku seseorang yang kehilangan kontrol dirinya sehingga melakukan hal-hal yang tidak wajar, baik atas dorongan nafsu, kepentingan sementara, maupun kepicikan pandangan. Istilah ini juga digunakan dalam arti mengabaikan nilai-nilai ajaran Ilahi.

Ayat diatas merupakan salah satu dasar yang ditetapkan agama dalam kehidupan sosial sekaligus ia merupakan tuntunan yang sangat logis bagi penerimaan dan pengamalan suatu berita. Kehidupan manusia dan interaksinya haruslah didasarkan hal-hal yang diketahui dan jelas. Manusia sendiri tidak dapat menjangkau seluruh informasi. Karena itu, ia membutuhkan pihak lain. Pihak lain itu ada yang jujur dan memiliki integritas sehingga hanya menyampaikan hal-hal yang benar, dan ada pula sebaliknya. Karena itu pula berita harus disaring, khawatir jangan sampai seseorang melangkah tidak dengan jelas atau dalam bahasa ayat di atas bi jahalah. Dengan kata lain, ayat ini menuntut untuk menjadikan langkah berdasarkan pengetahuan sebagai lawan dari jahalah yang berarti kebodohan, disamping melakukannya berdasar pertimbangan logis dan nilainilai yang ditetapkan Allah swt. Sebagai lawan dari makna kedua dari jahalah. 
Penekanan pada kata fasiq bukan pada semua penyampai berita karena ayat ini turun di tengah masyarakat muslim yang cukup bersih sehingga, bila semua penyampai berita harus diselidiki kebenaran informasinya, maka ini akan menimbulkan keraguan di tengah masyarakat muslim dan pada gilirannya akan melumpuhkan masyarakat. Namun demikian, perlu dicatat bahwa, bila dalam suatu masyarakat sulit dilacak sumber pertama dari satu berita sehingga tidak diketahui apakah penyebarnya fasik atau bukan atau bila dalam masyarakat telah sedemikian banyak orang-orang yang fasik, maka ketika itu berita apapun yang penting tidak boleh begitu saja diterima. Dalam konteks serupa, Sayyidina Ali ra. Berkata: "Bila kebaikan meliputi satu masa beserta orang-orang di dalamnya, lalu seorang berburuk sangka terhadap orang lain yang belum pernah melakukan cela, maka sesungguhnya ia telah menzaliminya. Tetapi, apabila kejahatan telah meliputi satu masa disertai banyaknya yang berlaku zalim, lalu seseorang berbaik sangka terhadap orang yang belum dikenalnya, maka ia akan sangat mudah tertipu.

Quraish Shihab menjelaskan lebih lanjut bahwa perlu dicatat banyaknya jumlah orang yang menyebar luaskan berita itu bukanlah jaminan kebenaran dari berita tersebut. Banyak factor yang harus diperhatikan, bahkan beliau menganalogikan dengan penyeleksian informasi yang dilalukan para ulama pada para perawi hadits Nabi, salah satunya ialah tentang penerimaan riwayat yang mutawatir, yang mana penerimaan riwayat disampaikan oleh sejumlah orang yang dinilai mustahil untuk sepakat berbohong. Diakhir penjelasan beliau menekankan lagi bahwa sebanyak apapun yang menyampaikan berita tidak menjamin status kebenarannya, Kata tushbihu pada mulanya berarti masuk di waktu pagi. Ia kemudian diartikan menjadi. Ayat diatas mengisyaratkan bagaimana sikap seorang beriman dikala melakukan satu kesalahan. Mereka, oleh akhir ayat diatas, dilukiskan sebagai fatushbihu ala ma fa'altum nadimin, yakni segera dan berpagi-pagi menjadi orang-orang yang penuh penyesalan. (Quraish Shihab, 2009)

\section{Bertabayyun analisis tafsir Al-Azhar QS Al-Hujurat ayat 6}

Turunnya QS Al Hujurat ayat 6 ini secara terangterangan membuktikan bahwa Bani Mustalhiq tidak berniat untuk membunuh al Walid. Bahkan ayat tersebut jelas sekali memberi nama yang hina untuk al Walid yaitu seorang fasiq, tegasnya seorang pembohong. Beberapa sahabat mengartikan fasiq sebagai kadzdzaab yang berarti pembohong, beberapa lainnya mengartikan sebagai orang yang tidak segan-segan menyatakan suatu perbuatan dosa. (Hamka, 2003)

Menurut buya Hamka ayat ini sangatlah jelas melarang manusia untuk segera percaya atau cepat percaya terhadap suatu berita yang dibawa oleh orang yang fasiq. Berita yang sampai jangan segera dibenarkan atau disalahkan, namun hendaklah diselidiki dahulu kebenarannya, Jangan sampai bertindak terlalu terburuburu dalam memberitakan suatu informasi atau perkara, sehingga akan berdampak buruk karena keputusan tersebut. Dan merugikan orang yang diberitakan tersebut karena telah mendapatkan hukuman, meskipun sebenarnya dia tidak bersalah. (Hamka, 2003) Nabi SAW sendiri berkata: "Menyelidiki dengan tenang adalah dari Allah dan tergopoh-gopoh adalah dari syaitan"

Hal tersebut dikuatkan oleh pendapat Ibnu Katsir yang dikutip oleh M. Khoirul Adha yakni umat Islam benar-benar harus meneliti berita yang dibawa oleh orang-orang fasiq dalam rangka mewaspadainya, sehingga tidak ada seorang pun yang memberikan keputusan berdasarkan perkataan orang fasiq tersebut. Karena pada saat itu orang fasiq tersebut berpredikat sebagai seorang pendusta dan berbuat kekeliruan, sehingga orang yang memberikan keputusan berdasarkan orang fasiq itu berarti ia telah mengikutinya dari belakang. (Adha, 2019) Sebagaimana Ahmad Mustafa Al-Maraghi yang berdasar pada kutipan M. Khoirul Adha menyebutkan bahwa orang-orang yang tidak peduli dalam melakukan ke-fasiq-an tentu tidak peduli pula untuk berbuat dusta, karena dusta termasuk cabang ke-fasiq-an. (Adha, 2019)

Kisah yang menjadi sebab turunya QS Al-Hujurat ayat 6 ini menjadi contoh teladan yang menjadi pedoman bagi kaum Muslimin bahwa tidak boleh cepat menerima suatu berita atau isu-isu yang belum tentu saja ujung pangkalnya. Namun kebanyakan orang lekas saja menerima dengan tidak berfikir panjang atas kebenarannya. (Rafsanjani, 2018)

Terdapat berita bahwa di Jakarta Timur, di atas satu pohon beringin terlihat ada orang bersayap terbang ke angkasa. Orang-orang pun datang berkerumun untuk menyaksikannya, padahal setelah dilihat tidak ada sama sekali. Ada lagi berita bahwa dua orang pemuda dan pemudi melakukan zina, lalu kedua badan mereka saling terkait tidak mau dipisahlah lagi. Ini terjadi di Jakarta Barat, maka berkerumun pulalah orang ke sana. Karena berita ini diperbuat seakan-akan berita yang benar-benar terjadi. Padahal setelah sampai ke tempat yang dikatakan itu sama sekali tidak terdapat apa yang dikatakan itu. (Rafsanjani, 2018)

Agama Islam telah memberikan pedoman yang jelas bagi umat islam untuk tidak lekas menerima informasi yang dibawa orang. Hendaklah diteliti atau ditabayyun-kan terlebih dahulu. Karena informasi yang seperti itu tak sedikit menjadikan manusia yang tidak bersalah menjadi korban. (Hamka, 2003)

\section{SIMPULAN}

1. Ath Thabari

Terdapat perbedaan qiraat fatabayyanu dibaca fatatsabbatu, namun kedua qiraat tersebut masyhur dan benar keduanya. Periksalah suatu berita dengan 
teliti, jangan sampai menimpakan musibah kepada orang lain yang tidak bersalah sebab ketidaktahuan keadaan yang sebenarnya. Adanya larangan untuk tergesa-gesa dalam mengambil tindakan terhadap suatu berita bisa berakibat sangat fatal. Sejatinya penyesalan datang terlambat jangan sampai menyesal karena akibat tindakan tersebut yang tergesa-gesa.

2. Ibnu Katsir

Menurut beliau bertabayyun merupakan bentuk kewaspadaan, predikat fasiq adalah sebagai seorang pendusta dan berbuat kekeliruan atau rusak. Allah melarang untuk mengikuti jejak orang yang rusak.

3. Al Misbah

Kedatangan orang fasiq kepada orang beriman merupakan hal yang jarang terjadi. Orang beriman adalah orang yang tidak mudah dibohongi dan akan meneliti kebenaran setiap informasi. Kata fasiq melukiskan buah yang telah rusak atau terlalu matang. Perlu memilah informan penting atau tidak, dan pembawa informasi dapat dipercaya atau tidak. Setiap berita harus disaring jangan sampai melangkah atau bertindak dalam keadaan yang kehilangan kontrol dan melakukan hal-hal yang tidak wajar.

4. Al Azhar

Secara jelas bahwa ayat ini membuktikan Bani Musthaliq tidak berniat membunuh al-Walid, bahkan walid dijelaskan sebagai orang yang fasiq, lebih jelas lagi adalah seorang pembohong.

Beberapa ulama berbeda pendapat dalam menafsiran kata fasiq. Ada yang menafsirkan kadzdzab (pembohong), atau orang yang tidak segan menyatakan suatu perbuatan dosa. Informasi yang datang jangan langsung dibenarkan atau ditidakkan, tetapi harus diselidiki dulu kebenarannya. Predikat fasiq adalah orang yang pendusta dan yang berbuat kekeliruan.

\section{DAFTAR PUSTAKA}

Abdullah bin Muhammad bin Abdurrahman bin Ishaq Alu Syaikh. (2009). Tafsir Ibnu Katsir, ter. M. 'Abdul Ghoffar Jakarta: Pustaka Imam Asy-Syafi'i

Abi Ja"efar Muhammad bin Jarir al-Tabari. (2007). Tafsir al-Tabari, jilid 23, Jakarta: Pustaka Azzam

Arifin, A. (2018). Kajian Komunikasi Massa Pada Surah Al-Hujurat Ayat 6. Jurnal Ilmiah Mahasiswa Raushan Fikr,7(1), 35-50. https://doi.org/https://doi.org/10.24090/jimrf.v7i1. 2205

Arikunto, Suharsimi. (1998). Prosedur Penelitian Suatu Pendekatan Praktek. Rineka Cipta: Jakarta

Brian Rafsanjani. (2018). Sikap Tabayyun Dalam AlQur'an Menurut Mufassir Dan Kontekstualisasi Pada Problematika Pemberitaan Media Sosial, Skripsi, Surabaya: Universitas Islam Negeri Sunan Ampel

Hamka. (2003). Tafsir Al-Azhar Singapura: Kerjaya Printing Industrie
M. Khoirul Adha. (2019). "Menangkal Berita Hoax Perspektif Al-Quran: Studi Komparasi Penafsiran Surat Al Hujurat ayat 6 antara Tafsir Ibnu Katsir dan Tafsir Al-Maraghi”, Skripsi, Salatiga: Institut Agama Islam Negeri Salatiga

Noor, M. (2018). Penilaian kualitas informasi sebagai bentuk sikap tabayyun ketika menerima informasi di sosial media dan internet. BIBLIOTIKA: Jurnal Kajian Perpustakaan dan Informasi, 2(1), 33-40. doi:http://dx.doi.org/10.17977/um008v2i12018p0 33

M. Quraish Shihab. (2009). Tafsir Al-Misbah, Jakarta: Lentera Hati

Zed, Mestika. (2004). Metodologi Penelitian Kepustakaan. Yogyakarta: Yayasan Obor Indonesia 